\title{
ANALISIS PENGENAAN TARIF PAJAK PROGRESIF PADA PAJAK KENDARAAN BERMOTOR BERDASARKAN THE FOUR MAXIMS DI KABUPATEN MINAHASA
}

\author{
Oleh : \\ Novita Asrilia Moningka \\ David Paul Elia Saerang \\ Harijanto Sabijono \\ Fakultas Ekonomi dan Bisnis, Jurusan Akuntansi \\ Universitas Sam Ratulangi \\ email : asriliamoningka@gmail.com
}

\begin{abstract}
Motor vehicle tax has strong enough role in the aceptance of local revenue. In North Sulawesi progressive tx on motor vehicles is valid from 12 january 2012 based on Law No. 28 of 2009 on local taxes and levies, based on the implementation of provincial regulations SULUT number 7 of 2011 concerning local tax applies to both private motor vehicle ownership and so, the two-wheeled vehicles and four-wheel except for a pick and dumb truck. Principles of taxation proposed by adam smith namely equality, certainly, conveinence of payment, efficiency. Research carried out the UPTD Tondano district of Minahasa. The analytical method used is descriptive analysis (qualittive) that analyzes comparing two different aspects of theory and practice which need to be met in order to know the differences. The purpose of this study is determine how the imposition of a progressive tax rate on motor vehicle tax is based on the four maxims. The result showed that the principle of taxation is still apropriate and relevant to be applied to the motor vehicle tax collection.
\end{abstract}

Keywords: Motor Vehicle Taxes, Progressive Tax Rates, The Four Maxims

\section{PENDAHULUAN}

\section{Latar Belakang}

Munculnya otonomi daerah menyebabkan terjadinya pergeseran paradigma sistem pemerintahan yang bercorak sentralisasi mengarah kepada sistem pemerintahan desentralisasi, yaitu dengan memberikan keleluasan/kewenangan kepada daerah dalam mewujudkan daerah otonom yang luas, dan bertanggung jawab untuk mengatur dan mengurus kepentingan masyarakat setempat sesuai dengan kondisi dan potensi wilayah yang ada serta faktor-faktor yang dapat menunjang pertumbuhan Pendapatan Asli Daerah.

Adapun sumber Pendapatan Daerah sebagaimana diatur dalam Undang-Undang Nomor 32 Tahun 2004 pasal 157, diantaranya adalah Hasil Pajak Daerah yang didalamnya yaitu Pajak Provinsi, dan penelitian ini berfokus pada salah satu jenis Pajak Provinsi yaitu Pajak Kendaraan Bermotor. Pajak Kendaraan Bermotor merupakan jenis pajak yang memberikan kontribusi yang cukup besar untuk penerimaan pajak bagi Kabupaten Minahasa. Peningkatan jumlah kendaraan bermotor memberikan sumbangan terhadap penerimaan Pajak Kendaraan Bermotor, sehingga dengan makin banyaknya kendaraan bermotor berarti potensi jumlah penerimaan Pajak Kendaraan Bermotor semakin banyak. Penerimaan dari Pajak Kendaraan Bermotor dialokasikan untuk berbagai sektor, tidak hanya bagi pembangunan jalan dan pembangunan sarana umum masyarakat tetapi juga untuk sektor pendidikan, kesejahteraan sosial, kesehatan, perumahan, dan sebagainya.

Asas-asas pemungutan pajak sebagaimana dikemukakan oleh Adam Smith menyatakan bahwa pemungutan pajak hendaknya didasarkan pada :

1. Equality; pemungutan pajak harus bersifat adil dan merata, yaitu pajak dikenakan kepada orang pribadi yang harus sebanding dengan kemampuan membayar pajak dan sesuai dengan manfaat yang diterima. 
2. Certainly; penetapan pajak itu tidak ditentukan sewenang-wenang. Oleh karena itu Wajib Pajak harus mengetahui secara jelas besarnya pajak yang terutang, kapan harus dibayar, serta batas waktu pembayaran.

3. Conveinence of payment; kapan wajib pajak itu harus membayar pajak sebaiknya sesuai dengan saat-saat yang tidak menyulitkan bagi Wajib Pajak.

4. Economy; secara ekonomi bahwa biaya pemungutan dan pemenuhan kewajiban pajak bagi Wajib Pajak diharapkan seminimum mungkin, demikian pula beban yang ditanggung Wajib Pajak.

Sebelumnya perhitungan Pajak Kendaraan Bermotor menggunakan Tarif Pajak Tunggal kemudian dilakukan pembaharuan perpajakan menggunakan Tarif Pajak Progresif. Pajak progresif ini berlaku pada kendaraan bermotor baru maupun bekas yang terhitung sebagai kendaraan kedua, ketiga dan seterusnya.

\section{Tujuan Penelitian}

Tujuan penelitian ini adalah Untuk mengetahui bagaimana penerapan Tarif Pajak Progresif pada Kendaraan Bermotor berdasarkan The Four maxims di Kabupaten MINAHASA.

\section{TINJAUAN PUSTAKA}

\section{Otonomi Daerah dan Desentralisasi}

Waluyo (2011:235) memaparkan bahwa secara resmi era otonomi daerah berlaku di Indonesia sejak 1 januari 2001. Sehingga daerah dituntut mencari berbagai alternatif sumber penerimaan yang dapat digunakan membiayai pengeluaran atau belanja daerah. Kebijakan ini merupakan penyelenggaraan pemerintah dari yang sebelumnya bersifat terpusat menjadi desentralisasi.

Kerangka otonomi daerah dan desentralisasi fiskal telah memberikan dimensi yang lebih jelas bagi daerah dalam rangka menyelenggarakan pemerintahan dan pelayanan serta pengelolaan keuangan berdasarkan prinsip transparansi, partisipasi dan akuntabilitas (Direktorat Jendral Perimbangan Keuangan Kementrian Keuangan RI, 2012:13).

\section{Konsep Dasar Pajak \\ Pengertian Pajak}

Menurut Dr. Rochmat Soemitro Pajak adalah iuran Rakyat kepada kas Negara berdasarkan UndangUndang (yang dapat dipaksakan) dengan tidak mendapat jasa timbal (kontraprestasi), yang langsung dapat ditunjukkan dan yang digunakan untuk membayar pengeluaran umum (Mardiasmo,2011:1).

\section{Fungsi Pajak}

Mardiasmo (2009:1) menyatakan bahwa fungsi pajak terbagi atas dua fungsi yaitu sebagai berikut:

1. Fungsi Anggaran (budgetair)

2. Fungsi Mengatur (Regurelend)

\section{Teori Pemungutan Pajak}

Teori-teori pemungutan pajak antara lain adalah : (Mardiasmo,2011:3)

1. Teori Asuransi

2. Teori Kepentingan

3. Teori Daya Pikul

4. Teori Bakti

5. Teori Asas Daya Beli

\section{Jenis Pajak}

Pajak dapat digolongkan kedalam tiga kelompok, yaitu berdasarkan golonganya, berdasarkan sifatnya, berdasarkan lembaga pemungutannya (Mardiasmo,2011:5).

\section{Sistem Pemungutan Pajak}

Sistem pemungutan pajak terdiri dari 3 yaitu: (Mardiasmo,2011:7)

\section{Official Assessment System}

Official Assessmet System adalah suatu sistem pemungutan yang memberi wewenang kepada Pemerintah (fiskus) untuk menentukan besarnya pajak yang terutang oleh Wajib Pajak.

2. Self Assessment System

Self Assessment System adalah sistem pemungutan pajak yang memberi wewenang kepada Wajib Pajak untuk menentukan sendiri besarnya pajak yang terutang.

3. With Holding System

With Holding System adalah suatu sistem pemungutan pajak yang member wewenang kepada pihak ketiga (bukan fiskus dan bukan Wajib Pajak yang bersangkutan) untuk menentukan besarnya pajak yang terutang oleh Wajib Pajak. 


\section{Asas Pemungutan Pajak}

Asas Pemungutan Pajak di Indonesia terbagi atas 3 bagian, yaitu: (Mardiasmo,2011:7)

1. Asas domisili (asas tempat tinggal

2. Asas Sumber

3. Asas Kebangsaan.

\section{Tarif Pajak}

Ada 4 macam tarif pajak yaitu:

1. Tarif sebanding/proporsional

2. Tarif Tetap

3. Tarif Progresif

4. Tarif Degresif

\section{Konsep Dasar Pajak Daerah}

Dasar Hukum Pajak Daerah

Dasar hukum pemungutan Pajak Daerah adalah Undang-Undang No. 28 Tahun 2009 tentang Pajak Daerah dan Retribusi Daerah.

\section{Pengertian Pajak Daerah}

Berdasarkan Undang-Undang Nomor 28 Tahun 2009, Pajak Daerah yang selanjutnya disebut Pajak adalah, kontribusi wajib kepada Daerah yang terutang oleh orang pribadi atau badan yang bersifat memaksa berdasarkan Undang-Undang, dengan tidak mendapatkan imbalan secara langsung dan digunakan untuk keperluan Daerah bagi sebesar-besarnya kemakmuran rakyat.

Jenis-Jenis Pajak Daerah

Pajak Daerah di Indonesia berdasarkan Undang-Undang Nomor 28 Tahun 2009 tentang Pajak Daerah dan Retribusi Daerah. Pajak Daerah terbagi menjadi dua, yaitu Pajak Provinsi dan Pajak Kabupaten/Kota.

Pajak Daerah dibagi menjadi dua bagian, yaitu:

1. Jenis Pajak Provinsi terdiri atas:

1. Pajak Kendaraan Bermotor

2. Bea Balik Nama Kendaraan Bermotor

3. Pajak Bahan Bkar Kendaraan Bermotor

4. Pajak Air Permukaan dan

5. Pajak Rokok

2. Jenis Pajak Kabupaten/ Kota terdiri dari:

1. Pajak Hotel

2. Pajak Restoran

3. Pajak Hiburan

4. Pajak Air Permukaan, dan

5. Pajak Penerangan Jalan

6. Pajak Mneral Bukan Logam dan Batuan

7. Pajak Parkir

8. Pajak Air Tanah

9. Pajak Sarang Burung Walet

10. Pajak Bumi dan Bangunan Perdesaan dan perkotaan, dan

11. Bea Perolehan Hak atas Tanah dan Bangunan.

\section{Konsep Pajak Kendaraan Bermotor}

\section{Pengertian Pajak Kendaraan Bermotor}

Menurut Undang-Undang Nomor 28 Tahun 2009 Pajak Kendaraan Bermotor adalah pajak atas kepemilikan dan/atau penguasaan kendaraan bermotor.

\section{Objek \& Subjek Pajak Kendaraan Bermotor}

Objek Pajak Kendaraan Bermotor adalah kepemilikan dan/atau penguasaan Kendaraan Bermotor (UndangUndang Nomor 28 Tahun 2009).

\section{Wajib Pajak Kendaraan Bermotor}

Wajib Pajak Kendaraan Bermotor adalah sebagai berikut: (Undang-Undang Nomor 28 Tahun 2009)

1. Wajib pajak kendaraan bermotor adalah orang pribadi/atau badan yang memiliki Kendaraan Bermotor. 
2. Dalam hal Wajib Pajak Badan, kewajiban perpajakannya diwakili oleh pengurus atau kuasa Badan tersebut.

3.

\section{Tarif Pajak Kendaraan Bermotor}

Menurut Undang-Undang Nomor 28 Tahun 2009 tentang Pajak \& Retribusi Daerah Tarif Pajak

Kendaraan Bermotor adalah sebagai berikut:

1. Tarif Pajak Kendaraan Bermotor pribadi ditetapkan sebagai berikut:

a. Untuk kepemilikan Kendaraan Bermotor pertama paling rendah sebesar $1 \%$ (satu persen) dan paling tinggi sebesar $2 \%$ (dua persen).

b. Untuk kepemilikan Kendaraan Bermotor kedua dan seterusnya tarif dapat ditetapkan secara progresif paling rendah sebesar 2\% (dua persen) dan paling tinggi sebesar 10\% (sepuluh persen).

\section{Dasar Pengenaan Pajak Kendaraan Bermotor}

1. Dasar pengenaan Pajak Kendaraan Bermotor adalah hasil perkalian dari 2 (dua) unsur pokok: (UndangUndang Nomor 28 Tahun 2009)

a. Nilai Jual Kendaraan Bermotor; dan

b. Bobot yang mencerminkan secara relatif tingkat kerusakan jalan dan/atau pencemaran lingkungan akibat penggunaan Kendaraan Bermotor.

\section{Konsep The Four Maxims}

Asas-asas pemungutan Pajak yang dikemukakan oleh Adam Smith yaitu: (Diana Sari, 2013:60)

1. Asas Equality (keadilan/kesamaan)

2. Asas Certainly (kepastian hukum)

3. Asas Conveinence of Payment (waktu yang pling baik dalam pemungutan pajak)

4. Asas Eficiency (Efisiensi)

\section{Penelitian Terdahulu}

Nugraha (2010) dengan judul penerapan Tarif Pajak Progresif terhadap Wajb Pajak Kendaraan Bermotor berdasarkan Peraturan Daerah Jawa timur Nomor 9Tahun 2010. Tujuan penelitian ini untuk mengetahui penerapan Tarif Pajak Progresif terhadap waib pajak kendaraan bermotor apakah sudah sesuai dengan Peraturan Daerah Jawa Timur nomor 9 Tahun 2010 tentang Pajak Daerah.Metode penelitian yang digunakan dalam penelitian ini adalah pemgembangan deskripsi kasus.Hasil penelitian menunjukkan penerapan tarif paajak progresif pada kendaraan bermotor menimbulkan dampak positif dan negatif bagi masyarakat. Persamaan dalam penelitian ini peneliti sebelumnya elakukan penelitian pada faktor yang sama yaitu Tarif Pajak Progresif. Perbedaannya adalah tempat dilakukannya penelitian dan penelitian sebeumnya mengkaji penerapan pajak progresif pada kendaraan bermotor berdasarkan peraturan daerah Jawa Timur Nomor 9 Tahun 2010.

Fajariani (2013) dengan judul analisis pengenaan tarif pajak progresif pada kendaraan bermotor berdasarkan The four maxims. Tujuan penelitian ini adalah berrtujuan untuk mengetahui penerapan tarif pajak progresif pada kendaraan bermotor apakah sudah sesuai dengan the four maxims. Metode penelitian yang digunakan adalah penelitian deskriptif. Hasil penelitian yang didapat adalah asas dalam The Four Maxims yang dikemukakan oleh Adam Smith kelihatannya sesuai untuk diterapkan. Persamaanya adalah peneliti sebelumnya melakukan penelitian pada faktor yang sama yaitu tarif pajak progresif. Perbedaannya tempat dilakukannya penelitian dan peneliti menggunakan peraturan undang-undangan yang terbaru.

Eugenia (2013) dengan judul analisis perbandingan sebelum dan sesudah pengenaan tarif pajak progresif pada kendaraan bermotor berdasarkan the four maxims. Tujuan diadakannya penelitian adalah untuk mengetahui bagaimana pengenaan tarif pajak progresif pada kendaraan bermotor berdasarkan the four maxims. Metode penelitian yang digunakan adalah deskriptif analitis. Hasil penelitiannya adalah pengeenaan atrif pajak progresif masih sangat sesuai dengan The Four Maxims yang dikemukakan oleh Adam Smith. Persamaannya adalah peneliti sebelumnya menggunakan faktor yang saa yaitu Tarif pajak progresif pada kendaraan bermotor. Perbedaannya adalah terletak pada objek peneitian dimana peneliti sebelumna mengangkat sebagai objeknya yaitu, Kota Manado, sedangkan dalam penelitian ini bertempat di Kabupaten Minahasa. 


\section{METODE PENELITIAN \\ Jenis Penelitian}

Menurut Sugiyono (2010:4) Metode penelitian pada dasarnya merupakan cara ilmiah yang digunakan untuk mendapatkan data yang objektif, valid dan realiabel dengan tujuan dapat ditemukan, dibuktikan dan dikembangkan suatu pengetahuan sehingga dapat digunakan untuk memahami, memecahkan, dan mengantisipasi masalah. Jenis Penelitian yang digunakan adalah jenis penelitian yang bersifat deskriptif (kualitatif).

\section{Tempat dan Waktu Penelitian}

Penelitian ini berlokasi di Unit Pelaksana Teknis Daerah (UPTD) Tondano Kabupaten Minahasa Induk, yang berada di Jln Manguni No. 8 depan Polres Tondano. Penelitian dilakukan selama 3 minggu pada bulan agustus.

\section{Prosedur Penelitian}

Susunan prosedur penelitian yang dilakukan dalam penelitian ini adalah sebagai berikut:

1. Mengajukan Permohonan Penelitian dengan cara memasukkan surat permohonan penelitian dengan persetujuan dari Fakultas Ekonomi \& Bisnis untuk melakukan penelitian pada objek-objek yang akan dipakai dalam penyusunan skripsi ini.

2. Melakukan observasi langsung ke objek penelitian untuk mengetahui gambaran umum mekanisme kegiatan pemungutan pajak.

3. Mengumpulkan data-data yang diperlukan sehubungan dengan penelitian untuk menjadi dasar acuan dalam penelitian.

4. Menganalisis apakah pengenaan tarif pajak progresif pada pajak kendaraan bermotor sudah sesuai dengan asas-asas pemungutan pajak atau tidak.

5. Menarik kesimpulan dari hasil penelitian yang dilakukan.

\section{Metode Pengumpulan Data}

1. Jenis Data

Dalam penelitian ini menggunakan dua jenis data yaitu:

a. Data kuantitatif adalah data penelitian berupa angka atau numerik.

b. Data kualitatif adalah data yang disajikan secara deskriptif dan tidak dapat diukur dengan skala numerik.

2. Sumber Data

Sumber Data yang digunakan dalam penelitian ini ada dua yaitu data primer dan data sekunder (Indriantoro dan Supromo, 2012:147).

\section{Teknik Pengumpulan Data}

1. Penelitian Lapangan; merupakan kegiatan kunjungan serta kegiatan pengumpulan data ditempat atau objek yang memiliki sumber data yang sesuai dengan penelitian, dan data diperoleh melalui cara:
a. Wawancara
b. Dokumenter

2. Penelitian kepustakaan adalah cara pengumpulan yang dilakukan dengan mengumpulkan data dari teoriteori yang diperoleh dari buku-buku, literatur, jurnal, serta bahan-bahan informasi lainnya yang berhubungan dengan masalah yang diteliti untuk digunakan sebagai landasan pemikiran teoritis bagi peneliti dalam membahas penelitian ini.

\section{Metode Analisis Data}

Metode analisis yang digunakan adalah metode deskriptif. Metode deskriptif adalah suatu metode dalam meneliti status kelompok manusia, suatu objek, suatu set kondisi, suatu sistem pemikiran, ataupun suatu kelas peristiwa pada masa sekarang dengan tujuan untuk membuat deskripsi, gambaran, lukisan secara sistematis, faktual, dan akurat mengenai fakta-fakta sifat, serta hubungan antar fenomena yang diselidiki.

\section{HASIL PENELITIAN DAN PEMBAHASAN Gambaran Umum Objek Penelitian Sejarah Singkat UPTD Tondano}

Pemungutan pajak kendaraan bermotor dilaksanakan pada satu kantor dikenal dengan istilah SAMSAT, dimana didalamnya terdapat kerjasama antara pihak POLRI yang mempunyai fungsi dan kewenangan dibidang registrasi dan identifikasi kendaraan bermotor, Pemerintah Daerah dalam hal ini Dinas Pendapatan Daerah dibidang pemungutan pajak kendaraan bermotor serta PT. Jasa Raharja yang berwenang dibidang penyampaian Sumbangan Wajib Dana Kecelakaan Lalu Lintas Jalan. 
Sebagai implementasi dari Manajemen Pendapatan asli Daerah Provinsi Sulawesi Utara dibentuk unitunit pelayanan pajak daerah di seluruh kabupaten/ Kota yang ada berupa Unit Pelaksana Teknis Dinas (UPTD) yang merupakan sub struktur dari Dinas Pendapatan Daerah Provinsi. UPTD menjalankan manajemen pemungutan pajak daerah yang melakukan pemungutan Pajak Daerah Provinsi.

UPTD Dinas Pendapatan Daerah Provinsi Sulawesi Utara dibentuk berdasarkan Peraturan Daerah Nomor 3 tahun 2008 tentang Organisasi dan Tata kerja Dinas Daerah Provinsi Sulawesi Utara dan Peraturan Gubernur Sulawesi Utara Nomor 96 Tahun 2008 tentang Pembentukan UPTD Dinas Pendapatan Daerah Provinsi Sulawesi Utara sebagaimana telah diubah dengan Peraturan Peraturan Gubernur Sulawesi Utara Nomor 13 Tahun 2011 tentang Pembentukan UPTD pada Dinas Pendapatan Daerah Provinsi Sulawesi Utara.

Pimpinan UPTD Tondano saat ini adalah Bpk. Ferdinand Sumarauw,M.si Wilayah layanan UPTD Tondano adalah Kabupaten Minahasa yang terdiri dari 23 kecamatan dan 272 Desa/ Kelurahan, yang dilayani dengan 1 kantor UPTD/ Samsat dan 1 unit Samsat Mobile yang melayani Wilayah Langowan, Kawangkoaan dan Pineleng. Jumlah Wajib Pajak Kendaraan Bermotor 41.232 Wajib Pajak.

\section{Motto, Visi dan Misi UPTD Tondano}

Motto UPTD Tondano : "Profesionalku, Pelayanan prima tujuanku”.

Visi UPTD Tondano; "Terdepan dalam pengelolaan pendapatan daerah dan pelayanan prima"

Misi UPTD Tondano:

1. Mengembankan kebijakan pendapatan daerah yang dapt diterima masyarakat partisipatif, bertanggungjawab dan berkelanjutan.

2. Mewujudkan pelayanan publik yang prima (excellent service) terpercaya, transparan dan akuntabel.

3. Mewujudkan sumber daya manusia aparatur yang potensial, integritas tinggi dan profesional serta membangun sisteem kelembagaan yang berbaasis kompetensi.

\section{Hasil Penelitian}

\section{Penerapan Tarif Pajak Progresif pada Kendaraan Bermotor di Kabupaten Minahasa}

Penentuan Urutan Pajak Progresif

Penentuan urutan Pajak Progresif terhadap kepemilikan kendaraan bermotor ditentukan berdasarkan tahun kendaraan yang tertua atau tahun ketika balik nama kendaraan bermotor terjadi (bila membeli kendaraan bekas).

Penerimaan Pajak Daerah Kabupaten Minahasa

Tabel 1 Realisasi Penerimaan Pajak Daerah UPTD Tondano Tahun 2012 \& 2013

\begin{tabular}{|c|c|c|c|}
\hline No. & JENIS PENERIMAAN & Realisasi Tahun 2012 & Realisasi Tahun 2013 \\
\hline 1. & PKB & $\begin{array}{ll}\mathrm{Rp} & 10.946 .641 .000\end{array}$ & $\mathrm{Rp} 13.421 .600 .200$ \\
\hline 2. & DENDA PKB & 357.435 .300 & $\begin{array}{ll}\mathrm{Rp} & 613.141 .400\end{array}$ \\
\hline 3. & $\mathrm{BBN}-\mathrm{KB}$ & $\begin{array}{ll}\mathrm{Rp} & 15.797 .468 .800\end{array}$ & Rp 22.749.689.700 \\
\hline 4. & DENDA BBN-KB & 20.255 .000 & 3.075 .000 \\
\hline 5. & PKAA & 4.161 .000 & 3.245 .700 \\
\hline 6. & P3AP & 1.209 .247 .400 & $\mathrm{Rp} \quad 1.467 .968 .650$ \\
\hline 7. & DENDA P3AP & - & - \\
\hline 8. & ALAT BERAT & 12.538 .200 & 10.696 .200 \\
\hline
\end{tabular}

Sumber: UPTD Tondano

Terlihat jelas dalam Tabel 1, jenis penerimaan Pajak Kendaraan Bermotor di tahun 2012 sebesar Rp 10.946.641.000,- menjadi Rp 13.412.600.200,- sehingga mengalami kenaikan, begitu pula dengan jenis penerimaan Denda PKB, BBN-KB dan P3AP mengalami kenaikan pada tahun 2013. 
Gambar 1 Perbandingan masing-masing komponen Pendapatan Daerah Tahun 2012 \& 2013

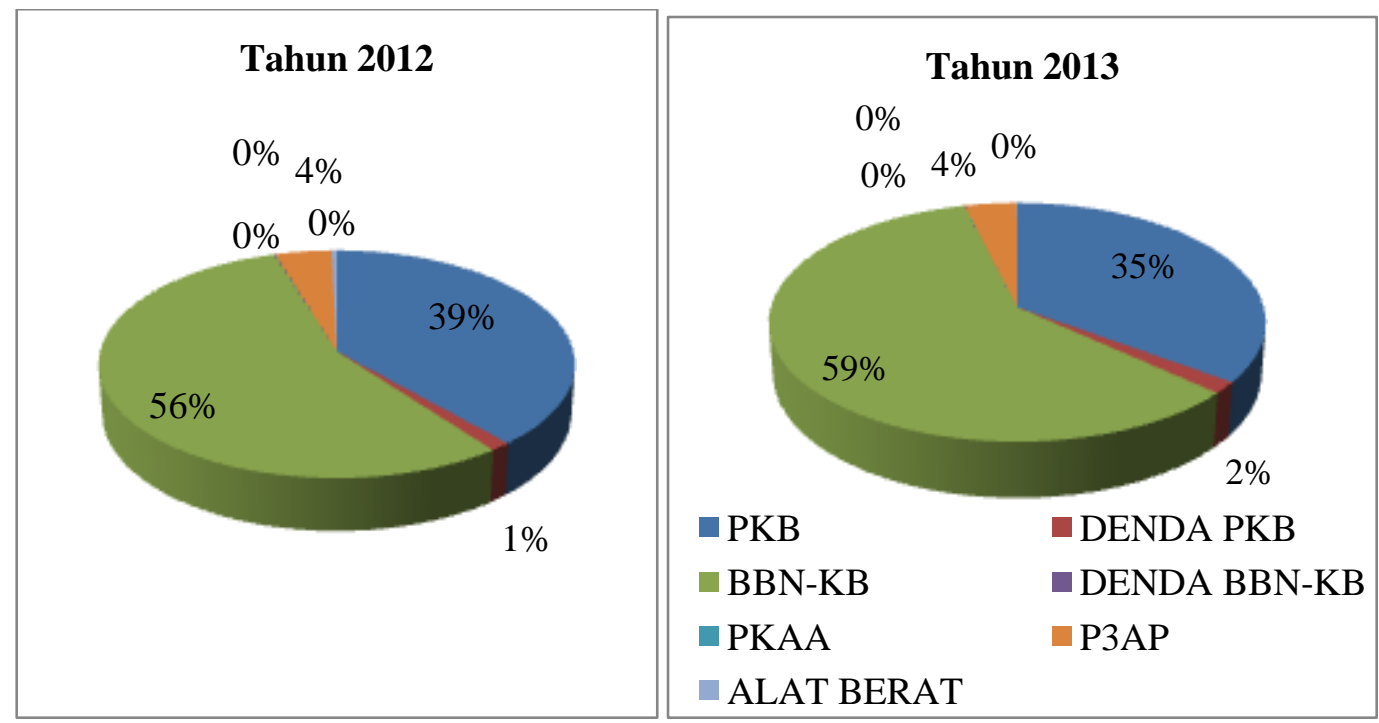

Sumber: UPTD Tondano

Gambar 2 terlihat bahwa Pajak Kendaraan Bermotor menempati urutan kedua dalam kontribusinya terhadap Pendapatan Asli Daerah. Terlihat tahun 2012 sampai 2013, Pajak Kendaraan Bermotor mengalami penurunan presentasi yakni 39\% menjadi 35\% dibandingkan dengan Bea Balik Nama Kendaraan Bermotor yang mengalami kenaikan dari $56 \%$ menjadi $59 \%$.

Tabel 2 Realisasi Penerimaan PKB Tahun Anggaran 2012 dan Tahun Anggaran 2013 UPTD Tondano

\begin{tabular}{l|lcr}
\hline \multirow{2}{*}{ NO } & BULAN & \multicolumn{2}{c}{ PENERIMAAN PAJAK } \\
\cline { 3 - 4 } & & $\begin{array}{c}\text { KENDARAAN BERMOTOR } \\
(\mathbf{R p})\end{array}$ & $\begin{array}{c}\text { TAH } \\
(\mathbf{R p})\end{array}$ \\
\hline 1 & JANUARI & 854.209 .300 & 1.178 .249 .000 \\
2 & FEBRUARI & 845.209 .800 & 974.478 .000 \\
3 & MARET & 944.124 .300 & 1.042 .913 .000 \\
4 & APRIL & 775.134 .900 & 933.801 .800 \\
5 & MEI & 868.689 .500 & 1.008 .475 .900 \\
6 & JUNI & 871.873 .800 & 870.996 .600 \\
7 & JULI & 896.970 .000 & 1.152 .651 .800 \\
8 & AGUSTUS & 955.503 .800 & 1.144 .613 .500 \\
9 & SEPTEMBER & 981.981 .800 & 1.279 .765 .800 \\
10 & OKTOBER & 1.082 .998 .300 & 1.417 .368 .900 \\
11 & NOVEMBER & 1.009 .977 .900 & 1.297 .499 .100 \\
12 & DESEMBER & 839.533 .500 & 1.120 .786 .800 \\
\hline & JUMLAH & 10.946 .641 .000 & 13.421 .600 .200 \\
\hline
\end{tabular}

Sumber: UPTD Tondano 
Gambar 3 Perbandingan Realisasi penerimaan Pajak Kendaraan Bermotor Tahun Anggaran 2012,2013 UPTD Tondano

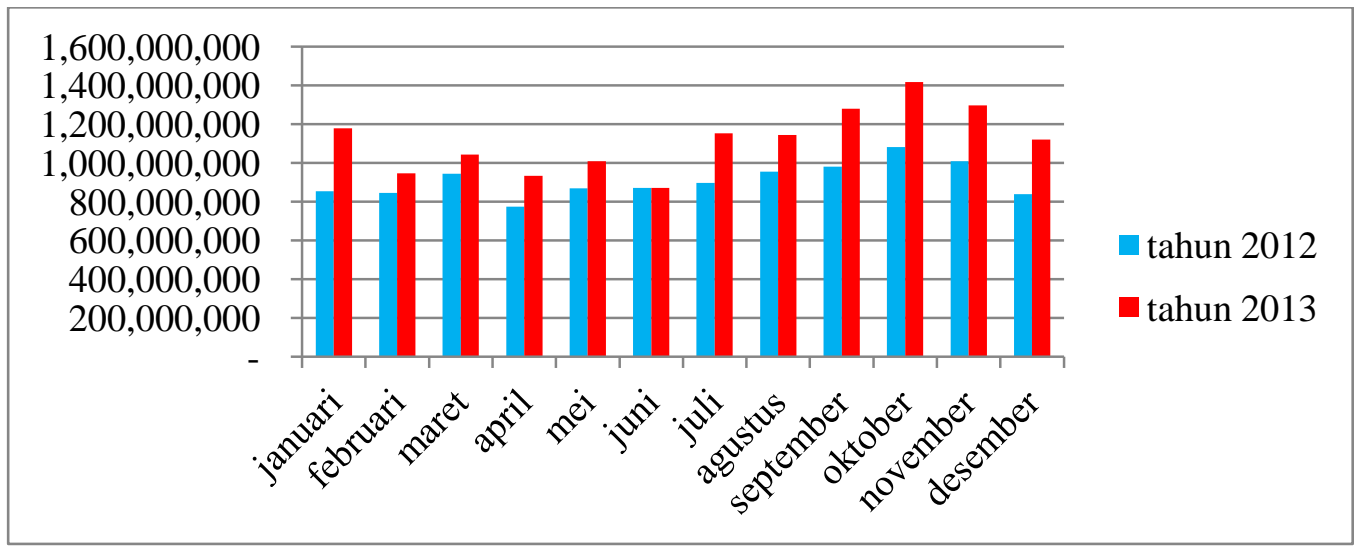

Sumber: UPTD Tondano (Hasil Olahan Penulis)

Tabel 2 dan Gambar 3 menunjukkan perbandingan penerimaan Pajak Kendaran Bermotor pada tahun 2013 setiap bulannya lebih meningkat dibandingkan tahun 2012. Dapat dilihat dari penerimaan bulan januari tahun 2012 adalah Rp 854.209.300 dan tahun 2013 sebesar Rp 1.178.249.000, begitu pula dengan bulan-bulan seterusnya.

\section{Penerapan Tarif Pajak Progresif pada Pajak Kendaraan Bermotor berdasarkan The Four Maxims}

\section{Asas Equality (Asas Keadilan)}

Setiap Wajib Pajak harus diperlakukan sama, adil dan merata. Berdasarkan asas ini pengenaan tarif pajak progresif pada Pajak Kendaraan Bermotor sangatlah adil karena dibandingkan dengan Tarif Pajak Kendaraan Bermotor diluar negeri, Indonesia merupakan Negara yang Tarif Pajaknya masih tergolong rendah, sehingga tidak dapat dikatakan bahwa Wajib Pajak tidak mampu membayar kewajiban perpajakannya. Ketika Wajib Pajak mampu memiliki Kendaraan Bermotor lebih dari satu unit, otomatis Wajib Pajak tersebut mampu membayar secara finansial kewajiban perpajakannya untuk kepemilikan pribadi. Sehingga dapat dikategorikan golongan masyarakat yang berpenghasilan lebih tinggi, maka dari itu semakin banyak kendaraan bermotor yang dimiliki maka semakin banyak pula jumlah pajak yang harus dibayarkan dan selayaknya dikenakan pajak yang lebih tinggi agar negara memiliki kemampuan lebih baik dalam menyediakan fasilitas umum bagi rakyatnya.

\section{Asas Certainly (Asas Kepastian Hukum)}

Dasar pengenaan Pajak Kendaraan Bermotor sangatlah jelas, Pengenaan Tarif Pajak Progresif pada Pajak Kendaraan Bermotor dipungut berdasarkan Peraturan Gubernur Sulawesi Utara Undang-Undang Nomor 7 Tahun 2011 tentang Pajak Daerah.

Secara yuridis formal, kelembagaan, sistem, prosedur, pola hubungan dan kewenangan manajemen pengelolaan pendapatan serta pemungutan Pajak Daerah didasarkan atas :

1. Undang-Undang Nomor 32 Tahun 2004 tentang Pemerintahan Daerah.

2. Peraturan pemerintah Nomor 58 tahun 2005 tentang pengelolahan Keuangan Daerah.

3. Undang-undang Nomor 28 Tahun 2009 tentang Pajak Daerah dan Retribusi Daerah.

4. Peraturan Gubernur Sulut Nomor 62 Tahun 2008 tentang Uraian Tugas Dinas Pendapatan Daerah Povinsi Sulawesi Utara.

5. Peraturan Menteri Dalam Negeri Nomor 24 Tahun 2013 Tentang Uraian Perubahan keempat Peraturan Menteri Dalam Negeri Nomor 29 Tahun 2012 Tentang Perhitungan Dasar PKB/BBN-KB, PERGUB Nomor 22 Tahun 2011 Tentang Perhitungan Dasar PKB/BBN-KB Tahun Pembuatan 2000 kebawah.

6. Peraturan Daerah Nomor 7 Tahun 2011 tentang pajak Daerah.

7. Peraturan Gubernur Sulawesi Utara Nomor 11 Tahun 2011 tentang pembentukan Unit Pelaksana Teknis Dinas (UPTD) Mitra pada Dinas Pendapatan Daerah Prov. Sulawesi Utara. 
8. Aturan tentang SAMSAT, Keputusan Bersama Kapolri Dirjen Pemerintah Umum dan Otonomi Daerah dan Direktur Utama PT. Jasa Raharja (Persero) Nomor SKEP /06 / X / 1999 No. 973-1220 dan nomor SKEP / 02 / X / 1999 Tanggal 15 Oktober 1999 Tentang pedoman tata laksana SAMSAT (Sistem Administrasi Manunggal Dibawah Satu Atap) ini bergerak dibidang pelayanan / perpajakan / pengurusan BPKB dan MUTASI Kendaraan Bermotor dari Daerah Satu ke Daerah Lainnya.

Tarif pajak Progresif pada Pajak Kendaraan Bermotor yang berlaku di Sulawesi Utara berdasarkan Undang-Undang Nomor 7 Tahun 2011 yaitu:

1. Untuk kepemilikan kedua sebesar $2 \%$ (dua persen).

2. Untuk kepemilikan ketiga sebesar $2,5 \%$ (dua koma lima persen).

3. Untuk kepemilikan keempat sebesar 3\% (tiga persen).

4. Untuk kepemilikan kelima sebesar 3,5\% (tiga koma lima persen).

Objek Pajak Kendaraan Bermotor adalah kepemilikan pibadi dan/atau penguasaan Kendaraan Bermotor. Kendaraan bermotor luar daerah yang digunakan lebih dari tiga bulan di dalam daerah, wajib melaporkan kepada Kepala Dinas. Sedangkan subjek dari Pajak Kendaraan Bermotor adalah Orang Pribadi atau Badan yang memiliki dan/atau menguasai Kendaraan bermotor.

\section{Asas Conveinence of Payment (saat yang paling tepat dalam membayar pajak)}

Waktu yang paling baik dalam pembayaran Pajak Kendaraan Bermotor adalah sesuai dengan tanggal dimana Wajib Pajak membeli Kendaraan Bermotor yang akan dikenai pajak. Karena pada saat Wajib Pajak membeli objek pajak, maka secara otomatis Wajib Pajak menerima penghasilannya. Berdasarkan sistem administrasi perpajakan pajak kendaraan bermotor memiliki tanggal jatuh tempo pembayaran, namun 3 bulan sebelum masa pajak berlaku Wajib Pajak sudah dapat membayarkan kewajiban perpajakannya. Tarif Denda STNK Pajak Kendaraan Bermotor wilayah Kabupaten Minahasa adalah sebesar 25\%.

\section{Asas Efficiency (Asas efisiensi)}

UPTD Tondano melaksanakan aktivitasnya berdasarkan mekanisme pelayanan samsat yang ada. Dimana terdapat fasilitas yang cukup memadai dalam rangka menunjang pemungutan pajak yang seminim mungkin untuk mendapatkan penerimaan pajak yang melebihi target yang ditetapkan. UPTD Tondano menyediakan fasilitas berupa SAMSAT Mobile untuk menjangkau para Wajib Pajak yang berada di daerah yang cukup jauh (wilayah langowan,kawangkoan dan pineleng) dari lokasi SAMSAT, juga menyediakan fasilitas pembayaran secara online agar Wajib Pajak lebih mudah dan cepat dalam membayarkan kewajibannya. Serta dengan adanya SDM yang berkualitas sehingga mampu menunjang pelayanan perpajakan yang ada.

\section{Pembahasan}

\section{Pengenaan Tarif Pajak Progresif pada Kendaraan Bermotor berdasarkan The Four Maxims}

Pemungutan Pajak Progresif pada Pajak Kendaraan Bermotor di Kabupaten Minahasa melalui UPTD Tondano sudah sesuai dengan asas-asas pemungutan pajak. Asas-asas pemungutan pajak yang dikemukakan oleh Adam Smith masih relevan untuk dapat diterapkan dan bisa menjadi acuan dalam perpajakan, yakni asasasas tersebut antara lain adalah kesamaan dan keseimbangan (equality), kepastian hukum (certainly), kenyamanan untuk membayar (conveinence of payment), dan efisiensi (efficiency). Dengan di dasari oleh asasasas pemungutan pajak yang ada, hak dan kewajiban negara/pemerintah maupun masyarakat mempunyai posisi yang sama kuatnya dalam menentukan bagaimana sebaiknya pajak harus diterapkan dengan dasar undangundang yang kuat, yaitu mengenai siapa yang akan dikenakan pajak, kapan akan dikenakan pajak, berapa jumlah pajak yang harus dibayar, sanksi yang akan dikenakan jika terlambat membayar pajak dan sebagainya.

\section{Asas Equality (asas keadilan)}

Asas Equality; yaitu pembebanan pajak harus sesuai dengan kemampuan Wajib Pajak. Berdasarkan asas ini penerapan pemberlakuan tarif pajak progresif bagi kepemilikan kendaraan bermotor kedua dan seterusnya sangatlah adil, karena Wajib Pajak yang memiliki kendaraan bermotor lebih dari satu unit dapat dikategorikan sebagai kelompok masyarakat yang memiliki penghasilan lebih besar (lebih dari cukup), sehingga pemungutan pajaknya harus lebih banyak.

\section{a. Menghitung Pajak Progresif pada Pajak Kendaraan Bermotor}

Untuk menghitung Pajak Progresif pada Kendaraan Bermotor adalah sebagai berikut:

Contoh: Tuan Roni memiiki tiga buah mobil masing-masing dengan Merek yang berbeda, yaitu:
1. Mobil Jazz (2007) NJKB X 1,5\%
2. Mobil Fortuner (2009) NJKB X $2 \%$
3. Mobil HILUX (2011) NJKB X 2,5\%
$=\operatorname{Rp} 181.000 .000 \times 1,5 \%$
$=\mathrm{Rp} 355.000 .000 \times 2 \%$
$=\operatorname{Rp} 2.715 .000$
$=\mathrm{Rp} 412.000 .000 \times 2,5 \%$
$=\operatorname{Rp} 7.100 .000$
$=\mathrm{Rp} 10.300 .000$
$\operatorname{Rp} 20.115 .000$ 
Untuk kepemilikan pertama Kendaraan Bermotor Tuan Roni dikenakan pajak sebesar 1,5\% dan pajak yang harus dibayar sebesar Rp 2.715.000, untuk kepemilikan kedua dikenakan pajak sebesar $2 \%$ dan harus membayar sebesar Rp 7.100.000 dan, untuk kepemilikan ketiga dikenakan pajak sebesar 2,5\% dan harus membayar pajak sebesar Rp 10.300.000. Jadi, Pajak yang harus dibayar Tuan Roni selama satu periode adalah sebesar Rp20.115.000.

\section{Asas Certainly (Asas kepastian hukum)}

Berdasarkan asas ini dasar pengenaan pajak, tarif pajak, objek Pajak, subjek Pajak dan sebagainya sudah sangat jelas sehingga tidak ada kemungkinan bagi Wajib Pajak untuk tidak membayarkan kewajiban Perpajakannya. Berdasarkan asas ini UPTD Tondano telah melakukan pemungutan pajak sesuai dengan Peraturan pemerintah yang ada, karena peraturan pemerintah yang ada sudah sangat jelas dan telah dilaksanakan dengan baik.

\section{Asas Conveinence of Payment (waktu yang paling baik dalam membayar pajak)}

Asas Conveinence of payment yaitu pajak dipungut pada saat yang paling baik, yakni pada saat yang paling dekat dengan diterimanya penghasilan/pendapatan yang dikenai objek pajak. Untuk pembayaran pajak kendaraan bermotor UPTD Tondano melaksanakan pemungutan pajakyaitu sesuai dengan tanggal pembelian kendaraan bermotor atau saat dimana Wajib Pajak menerima penghasilan.

Pajak Kendaraan Bermotor apabila sudah jatuh tempo masa berlaku STNK (Surat Tanda Nomor Kendaraan ) belum melakukan perpanjangan, maka akan dikenakan Denda PKB (Pajak Kendaraan Bermotor) dan SWDKLLJ (Sumbangan Wajib Dana Kecelakaan Lalu Lintas Jalan), perhitungannya sebagai berikut:

\section{a. Perhitungan Denda PKB:}

Bapak Liam memiliki Kendaraan Bermotor roda empat berupa mobil dan terlambat membayarkannya selama 6 bulan, Total Pajak Kendaraan Bermotor sebesar Rp 230.000 perhitungannya adalah sebagai berikut:

Jumlah PKB X Tarif Denda PKB X lamanya denda

Rp 230.000 X 25\% X 6/12 = Rp 28.750

Untuk perhitungan denda SWDKLLJ dilakukan oleh Jasa Raharja.

\section{Asas efficiency (efisiensi)}

Berdasarkan asas efisiensi, pengenaan tarif pajak progresif pada kendaraan bermotor melalui pelayanan pemungutan pajak dan informasi pemungutan pajak yang jelas dan cukup baik, UPTD Tondano berusaha menekan pengeluaran/biaya pemungutan pajak sekecil mungkin dengan penggunaan fasilitas-fasilitas yang ada dan berusaha mencapai pendapatan pajak melebihi target yang telah ditetapkan.

Tabel 3 Target dan Realisasi Penerimaan Pajak Kendaraan Bermotor tahun 2012 dan tahun 2013

\begin{tabular}{lclc}
\hline $\begin{array}{c}\text { Tahun } \\
\text { Penerimaan }\end{array}$ & $\begin{array}{c}\text { Target Tahun } \\
\text { Anggaran }\end{array}$ & Realisasi penerimaan & $\begin{array}{c}\text { \% dari } \\
\text { target }\end{array}$ \\
\hline 2012 & $\mathrm{Rp} 10.671 .000 .000$ & $\mathrm{Rp} 10.926 .206 .900$ & $102,39 \%$ \\
2013 & $\mathrm{Rp} \mathrm{11.618.300.000}$ & $\mathrm{Rp} \mathrm{13.421.600.200}$ & $115,44 \%$ \\
\hline Jumlah & $\mathrm{Rp} \mathrm{22.289.300.000}$ & $\mathrm{Rp} \mathrm{24.347.807.100}$ & $109,23 \%$ \\
\hline
\end{tabular}

Sumber: (diolah oleh Penulis)

Tabel 3 menunjukkan jumlah penerimaan pajak kendaraan bermotor pada tahun 2012 sebesar Rp 10.926.206.900 atau 102,39\% dari target untuk tahun anggaran 2012, dimana menunjukkan telah melebihi target yang telah ditetapkan. Dan untuk penerimaan Pajak Kendaraan Bermotor tahun 2013 sebesar Rp 13.421.600.200 atau 115,44\% dari target tahun anggaran 2013, dimana telah melebihi target yang telah ditetapkan.

Dari tabel diatas terlihat jelas bahwa UPTD Tondano melaksanakan asas efisiensi dengan cukup baik, dimana penerimaan pajak kendaraan bermotor di tahun 2012 \& tahun 2013 telah melebihi target yang ditetapkan.

\section{KESIMPULAN}

Berdasarkan uraian di atas dapat ditarik kesimpulan sebagai berikut:

1. Tarif Pajak Progresif merupakan pengenaan Tarif Pajak yang kenaikan presentasenya semakin meningkat untuk kepemilikan Kendaraan Bermotor pribadi lebih dari satu unit. 
2. Tarif Pajak Progresif pada Kendaraan Bermotor mulai diberlakukan di Sulawesi Utara sejak tanggal 12 Januari 2012.

3. Dasar Pengenaan Tarif Pajak Kendaraan Bermotor adalah perkalian antara Nilai Jual Kendaraan Bermotor dan Bobot yang mencerminkan secara relatif kadar kerusakan jalan dan/atau pencemaran lingkungan akibat penggunaan kendaraan bermotor

4. Penerapan Tarif Pajak Progresif pada Pajak Kendaraan Bermotor diatur dalam Perda Nomor 7 Tahun 2011 Tentang Pajak Daerah (Sulawesi Utara). Pajak Progresif diterapkan bagi kendaraan bermotor pribadi baik roda dua dan roda empat kecuali pada kendaraan jenis pick up dan Dumb truck dengan nama pemilik dan alamat tempat tinggal yang sama.

5. Penentuan urutan pajak progresif berdasarkan tahun kendaraan yang tertua atau tahun ketika balik nama kendaraan bermotor terjadi (bila membeli kendaraan bekas).

6. Pengenaan Tarif Pajak Progresif pada Pajak Kendaraan Bermotor berdasarkan "The Four Maxims" masih dianggap relevan, yaitu asas-asas pemungutan pajak yang dikemukakan oleh Adam Smith yang diantaranya adalah kesamaan dan keseimbangan (equality), kepastian hukum (certainly), asas ketepatan waktu (conveinence of payment), dan asas efisiensi (economic of collection).

\section{A. Saran}

Berdasarkan pada hasil pembahasan, maka hal-hal yang dapat disampaikan sebagai saran/masukan kepada pihak yang terkait dalam pelaksanaan pemungutan Pajak Progresif pada Pajak Kendaraan Bermotor berdasarkan The Four Maxims, khususnya di UPTD Tondano Kabupaten Minahasa sebagai berikut:

1. Melakukan survey secara berkala untuk pembaharuan data Wajib Pajak khususnya untuk kendaraan yang sudah dijual atau menjadi hak milik orang lain untuk segera langsung melaporkan BBN-KB.

2. Dengan semakin meningkatnya penerimaan Pajak melalui Pajak Kendaraan Bermotor perlu dimbangi dengan fasilitas maupun kualitas pelayanan dalam pembayaran pajak yang ada di UPTD Tondano, agar para Wajib Pajak merasa puas dan nyaman dengan pelayanan yang ada.

3. Untuk memudahkan dan mempercepat pelayanan di UPTD Tondano/Samsat perlu dilakukan penambahan loket-loket pembayaran sehingga tidak terjadi penumpukkan antrian yang terlalu banyak, agar pelayanan menjadi efektif dan efisien.

4. Pembayaran secara online sebaiknya segera diterapkan, untuk memudahkan Wajib Pajak dalam membayarkan kewajiban Perpajakannya.

\section{DAFTAR PUSTAKA}

Diana Sari.2013.Konsep Dasar Perpajakan.Refika Aditama.Bandung.

Direktorat Jendral Pertimbangan Keuangan, Kementrian Keuangan Republik Indonesia. 2012. Pelengkap Buku Pegangan Penyelenggaraan Pemerintahan dan Pembangunan Daerah.Jakarta.

Fajriani. 2013. Pengenaan Tarif Pajak Progresif pada Kendaraan Bermotor berdasarkan "The Four Maxims". Jurnal Vol 1 No 2. Universitas Surabaya. Surabaya. http://ejournal.unesa.ac.id/index.php/jurnalakuntansi/article/view/739/baca-artikel. Diakses 22 Maret 2014.

Mardiasmo. 2009. Perpajakan. ANDI.Yogyakarta.

Mardiasmo. 2011. Perpajakan. ANDI.Yogyakarta.

Nugraha.Haris. 2010.Penerapan Pajak Progresif terhadap Wajib Pajak Kendaraan berdasarkan peraturan Daerah Jawa Timur Nomor 9 Tahun 2010 tentang Pajak Daerah. Jurnal Ilmiah. Universitas Brawijaya. Malang. http://hukum.ub.ac.id/wp-content/uploads/2013/01/Jurnal-Harist-Agung-NugrahaDiakses 22 Maret 2014.

Sugiyono.2010. Metode Penelitian Kualitatif Kuantitatif dan R\&D. Alfabeta.Bandung.

Undang-Undang Republik Indonesia Nomor 28 Tahun 2009 tentang Pajak Daerah \& Retribusi Daerah. Jakarta.

Waluyo.2011. Perpajakan Indonesia, Edisi 10.Salemba Empat.Jakarta. 